\title{
SUPERSTRUCTURE OF ISO/TS 16949 FOR THE MEASUREMENT OF MATERIAL-TECHNOLOGICAL PARAMETERS OF THE PRODUCTS IN AUTOMOTIVE PRODUCTION
}

\author{
Andrea SEŇOVÁ \\ Technical University of Kosice \\ Lenka ŠTOFOVÁ, Petra SZARYSZOVÁ, Jaroslav DUGAS \\ University of Economics in Bratislava
}

\begin{abstract}
:
The paper is aimed at measuring innovation and qualification of technological operations in automotive production within the quality management system. Quality requirements according to ISO/TS 16949 promote a process approach for the design and development, production, installation and servicing of automotive products, which can result in increased quality, reduced variation and increase of efficiency. The solution focuses on the process of approval of parts in series production (Production Part Approval Process - PPAP). The PPAP purpose is to determine whether an organization properly understood all customer requirements listed in the specifications and records of the technical design of the product. PPAP further verifies that the process has the potential to produce a product in series production so that customer requirements will be met, in actual production volume and at the agreed rate of production. Specifically, a toothed winch of hydroelectric generator is solved by the case study.
\end{abstract}

Key words: automotive production, comprehensive quality, supply chain, series production, part approval process

\section{INTRODUCTION}

The automotive industry is a complex manufacturing process as well as the chain of suppliers to whom the producer of automobiles must be fully relied on. For automobile producer it is important to have suppliers who can quickly and accurately respond to its requirements, to adapt quickly to developments in the automotive industry and to be reliable. Automobile producers require suppliers that have their processes under control, understand the specific requirements of their customers and focus on continuous improvement. On the current world market, both manufacturers and consumers require guarantees for the quality of products and services. Now it is no longer sufficient to provide products and services that conform to certain standards. All manufacturers and service organizations need to demonstrate their capability to provide a continuous quality for their products and services. That is why all businesses and public organizations need to set up quality systems enabling them to guarantee that required quality is obtained at the appropriate cost [1]. An essential aspect of quality management system according to ISO/TS 16949 is to focus on the specific requirements of automotive customers (specific quality requirements in terms of products, processes and systems)

\section{LITERATURE REVIEW}

ISO/TS 16949:2002 made its debut in 2002 with a roll out meeting by the International Automotive Task Force (IATF). It was clear from its inception that ISO/TS 16949:2002 was different than its predecessor, QS-9000, for many reasons. The changes in ISO/TS 16949:2002 stemmed from the dissatisfaction of the industry in how QS-9000 was being implemented. The general feeling in the automotive industry was that there were many organizations registered to QS-9000 that were not at a QS-9000 level. The IATF tried to improve the overall situation with two important institutional changes: creating its own oversight body and scheme, and reducing the number of registrars that could audit to ISO/TS 16949:2002 from several hundred to approximately 55 [2]. 
Organizations operating in the automotive industry which want to be leading suppliers of major automobile producers in the world, should receive certification of their system in accordance with ISO/TS 16949, as the contractual obligation they are imposed by most producers. The purpose of this International Standard is to develop a quality management system that will generate continuous improvement through prevention, reduction of variation and waste minimization, and throughout the supply chain of the automotive industry. Taking differences in national approaches, practices and constraints into account, it is to be recognised that future developments and decisions will have to be extended in order to include further important aspects and, finally, to enhance an acceptance and confidence in the safety-related planning work as well as the waste management and disposal solutions [3]. Advanced technologies can be applied in all manufacturing and processing industries and form an important element in the supply chain of many high value industrial businesses [4]. The tools of continuous improvement include the following methods: SPC (Statistical Process Control), MSA (Measurement System Analysis), PFMEA (Potential Failure Modes and Effects Analysis), APQP (Advanced Product Quality Planning), and PPAP (Production Part Approval Process) [5].

According to ISO TS 16949 the supplier is requested to perform a production process and product approval to achieve the release for series production [6]. The PPAP defines the procedures governing the operation of the approval of parts and components for a mass production, which constitutes the basis for the certification and approval of products and materials that make up the manufacturing process and control during production. If this control confirms all customer requirements that are verified and listed in the product specification, then it should have a positive evaluation before putting into series production. With increasing requirements for more complex structures in the automobile there is also a requirement linked with a higher quality of product components. Therefore, there is an effective quality assurance tool used for assessment and verification of capabilities of the production process and it is performed using process capability indexes [7].

These findings are realized with the use of control cards and the calculations of the process capability and performance indicators. In case of noncompliance detailed, substantive analysis and specific corrective action is undertaken [8].

The automotive industry is a supplier and customer, supplied extensively and in a quality assurance, performance and safety of the final product, industry associations have developed several standards including the PPAP. It defines a consistent production and approval processes to ensure supplier's understanding of automobile specifications and continually supply of parts to meet customer requirements. The subject of the evaluation and the control is the characteristics of the products and services that are the result of processes or characteristics of the processes. Many characteristics are measurable characteristics for which the best-known values were determined, called nominal values [9].

A mistake often happens in an enterprise's practice of associating the controlling with the control, although it contains certain control elements, technologies [10].

Controlling is a tool used by the top management of an enterprise when collecting and processing the information on the costs and revenues of the given enterprise. Particularly the importance of this information is emphasised for the purpose of strategic enterprise management [11].

The motivation of employees, their efficiency, productivity, and assessment will be increased by the impact of the manpower management aspects, which will provide the automotive business effectiveness increase [12].

In the context of process capability analysis, the results of most processes are dominated by two or even more quality characteristics, so that the assessment of process capability requires that all of them are considered simultaneously. In recent years, many researchers have developed different alternatives of multivariate capability indices using different approaches of construction [13].

\section{MATERIAL AND METHODS}

\section{Analysis of the PPAP in the selected organization of au-} tomotive production

The paper defines the objectives and goals of qualification of the toothed drive/shaft for series production of enterprise in the automotive industry by SK NACE 29320. The toothed shaft, whose production is a subject to qualification, is a key element of the final product - toothed hydroelectric generator. Its rotation ensures the conversion of a mechanical energy to a hydraulic one. The working principle of the toothed hydroelectric generator is shown in the Fig. 1.

Intermediate product for the toothed shaft (Fig. 1) is a steel rod AISI 8620 (DIN 21NiCrMo $)$. The toothed shaft is processed by a series of technological operations, including turning, milling, heat treatment, grinding, deburring and superfinishing.

The organization must have records of the test results of a material or product functionality if they are specified in the design documentation or plan to control and management [14].

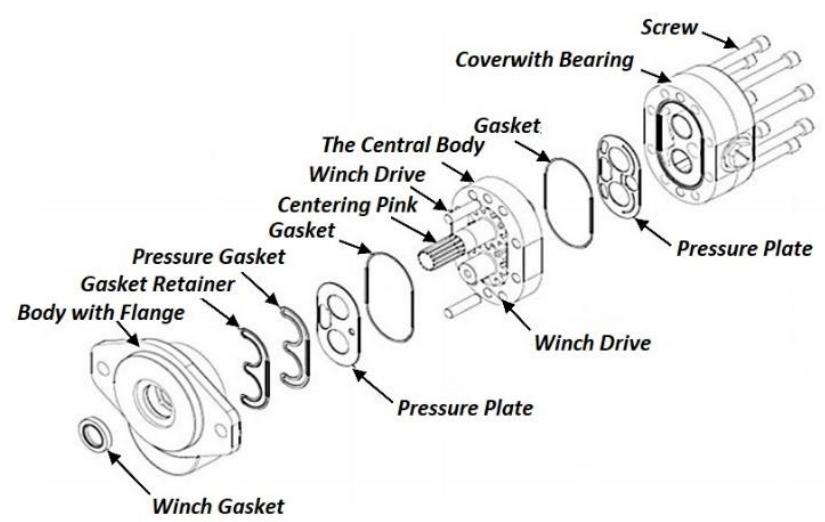

Fig. 1 Mechanical drawing of a toothed hydroelectric generator 
If they are in a design documentation or a control plan and a management listed the chemical, physical requirements or metallurgical tests, their organization must make them for all parts and materials of the product. All tests required in the design documentation and related specifications must be made of the requisite number of products, documented in an acceptable format and actual results [15].

The material test report must include [16]:

- the level of change in a construction documentation of tested parts,

- the date of testing,

- the name of subcontractor material, and when it is required by the customer, a code number from the list of approved subcontractors to customers.

If the required performance tests are in the design documentation or control and management plan, the organization shall carry out tests for all parts or materials of the product [17].

The test report must identify and contain [18]:

- the level of change in a construction documentation of tested parts,

- $\quad$ any documents of approved technical modifications which have not been included in the design documentation,

- the date of testing.

All tests required in the design documentation or related specifications must be documented [19].

Status of the product approval process at the customer Organization must ensure that after the authorization future production will continue to meet all customer requirements [20]. The algorithmic flowchart of the PPAP is documented in Fig. 2.

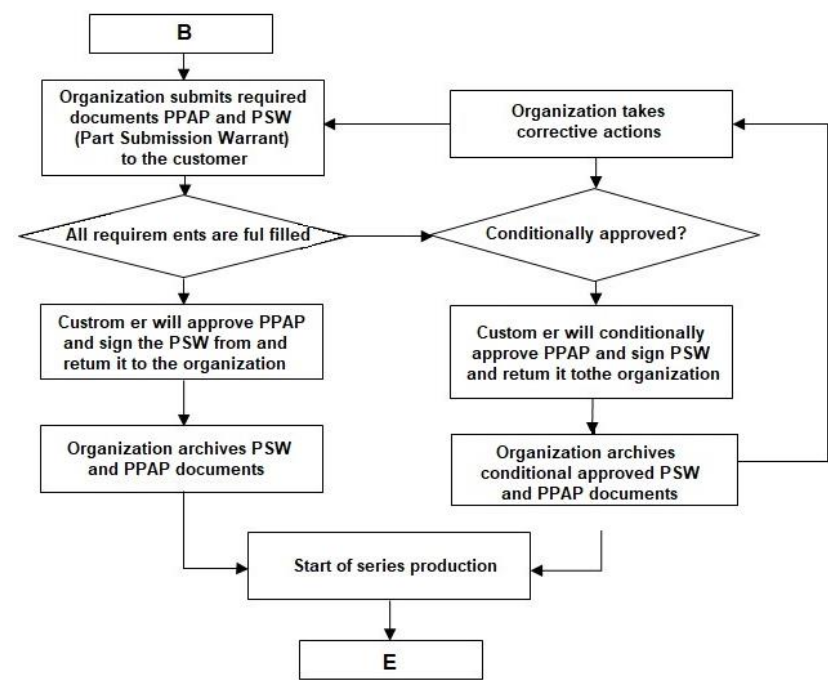

Fig. 2 Algorithmic flowchart of the PPAP

Source: [20].

Records of the PPAP must be irrespective of the level of transmission maintained all the time, after which the product is active plus one calendar year [21]. The Production Part Approval Process (PPAP) provides customers with evidence that: a) Component suppliers have understood their requirements;

b) The product meets the customer's requirements;

c) The production process is capable of consistently producing conforming product.

The PPAP process is currently governed by the PPAP manual published by the Automotive Industry Action Group (AIAG) [22].

Production of toothed shafts is divided into the following parts [23]:

- operations of turning, milling and heat treatment is provided by an external company,

- grinding, deburring and superfinishing are performed in the examined production plant,

- after final operations toothed shafts are preserved, packed, and moved to the expedition from where they are sent to the internal customer (assembly plant).

Following Fig. 3 shows Material and information flow of toothed shafts production according to [23].

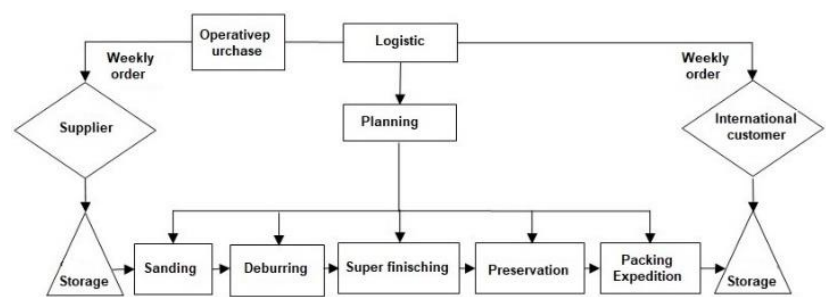

Fig. 3 Material and information flow of toothed shafts production

Source: [23].

An important part of the review of design documentation was to identify the key features of bearing diameters after superfinishing. For each part of the production process there was drawn up a separate FMEA of the process. Each FMEA starts with identifying the parts and ends on next operation. For superfinishing it is completed by preservation and packaging [24].

Because reviewed processes of machining (grinding and superfinishing) were based on customer requirements calculated from the measured data prior performance indexes $P_{p}$ and $P_{p k}$ because the file contains statistics from the perspective of a small amount of data (50) for each dimension and the data were collected in a short period of time. In literature there are process performance indexes $P_{p}$ and $P_{p k}$ referred also as "short-term capability" or "initial process capability" [25].

\section{RESULTS AND DISCUSSION}

The measured values of each bearing diameters were sent from the optical measuring instrument to the database for processing in a statistical software qs-Stat according to an evaluation strategy for the PPAP [26]. After completion of all production and control operations the software qsStatgenerated graphical outputs and final resulting reports were necessary. Software qs-Stat carries out all the necessary analyses and calculations according to a set of evaluation strategy for the PPAP, allowing to define the specific requirements of individual users, such as minimal 
requirements for $P_{p}$ and $P_{p k}$, or minimal number of evaluable data. qs-STAT record data from various sources, consolidate them and maintain quality control charts [27]. Calculation of the performance indexes for the bearing diameter D1 shows Fig. 4.

Progressions of measured values and histograms for all audited process and key features meet the characteristics of the stable process described by a normal distribution of values without systematic impacts (Fig. 5).

The measured values (Fig. 5) show little variance of values, while the average value shifts toward the upper tolerance limit. At first glance it is clear that the value of $P_{p}$ is above the set point value of 1.83 and $\mathrm{P}_{\mathrm{pk}}$ is relatively worse.

From the calculated performance indexes, listed in Table 1 , we can note that both verified production processes, grinding and superfinishing of bearing diameters of the toothed shafts, which are defined as process and key elements meet the requirements specified by the customer: $P_{p} \geq 1.83$ and $P_{p k} \geq 1.33$.
Table 1 Complete results of the initial performance study

\begin{tabular}{|c|c|c|c|c|c|c|}
\hline 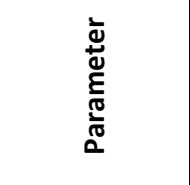 & $\begin{array}{l}\frac{9}{\frac{\pi}{\pi}} \\
\frac{\pi}{20} \\
\frac{0}{0}\end{array}$ & $\overline{\mathbf{x}}$ & $\sigma$ & $\mathbf{P}_{\mathbf{p}}$ & $\mathbf{P}_{\mathrm{pk}}$ & 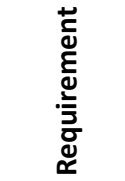 \\
\hline $\begin{array}{l}\text { Bearing } \\
\text { diameter } \\
\text { D1 - grinding }\end{array}$ & $\begin{array}{l}22.225 \\
\pm 0.005\end{array}$ & 22.2267 & 0.0005689 & 2.93 & 1.94 & \\
\hline $\begin{array}{l}\text { Bearing } \\
\text { diameter } \\
\text { D2 - grinding }\end{array}$ & $\begin{array}{l}22.225 \\
\pm 0.005\end{array}$ & 22.2258 & 0.0007632 & 2.18 & 1.82 & \\
\hline $\begin{array}{l}\text { Bearing } \\
\text { diameter } \\
\text { D3 - superfin- } \\
\text { ish }\end{array}$ & $\begin{array}{l}22.220 \\
\pm 0.005\end{array}$ & 22.2216 & 0.0007171 & 2.32 & 1.59 & $\begin{array}{l}P_{p} \geq 1.83 \\
P_{p k} \geq 1.33\end{array}$ \\
\hline $\begin{array}{l}\text { Bearing } \\
\text { diameter } \\
\text { D4 - superfin- } \\
\text { ish }\end{array}$ & $\begin{array}{l}22.220 \\
\pm 0.005\end{array}$ & 22.2073 & 0.0009491 & 1.94 & 1.64 & \\
\hline
\end{tabular}



Fig. 4 Calculation of the performance indexes for the bearing diameter D1

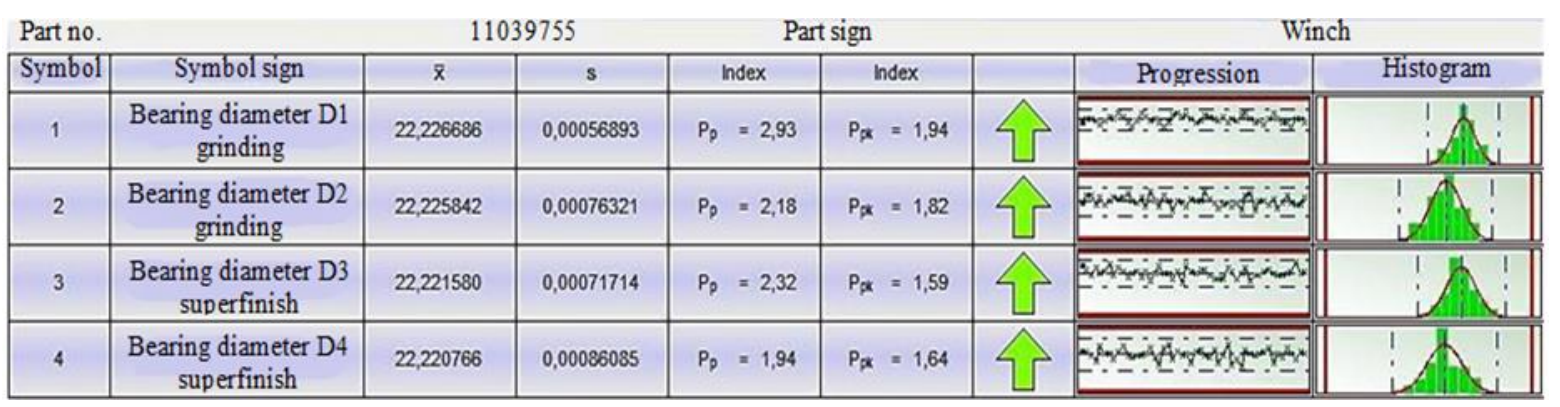

Fig. 5 Summary of the results of the initial capability study 
Based on the results and knowledge gained in the initial evaluation of the performance of the process of grinding and superfinishing there were designed activities to improve the long-term capability $C_{p}$ and $C_{p k}$ during the subsequent series production:

- to create plans for measuring on optical measuring devices for all types of toothed shafts,

- to equip individual workplaces within the production island of measuring instruments (callipers, micrometres, pass metres) required in the control and management technology or in technological and control procedures,

- to provide two PC terminals with installation of the software qs-Stat, Procella module and create separate plans for measuring on-line data sent from measurements of the width of the teeth after grinding and measurement of surface roughness after superfinishing,

- to define clamping of the toothed shaft in the control procedure when measured by the measuring device identification recess to the lower tip, which ensures correct assignment of measuring dimensions by measuring program,

- to make plans for control and management, technological and control procedures, mechanical drawings and other documentation and mechanical drawings on PC terminals,

- to define the downforce of superfinishing heads and other parameters of superfinishing in the technological and control plan for superfinishing (downforce, frequency, and time of superfinishing),

- to monitor continuously the long-term capability indexes for individual process operations (grinding and superfinishing) to revise the results of the measurement frequency and superfinishing allowance (currently $5 \mu \mathrm{m}$ ). Using the PPAP methodology and support tools for planning, management, and quality improvement there has been designed and implemented a production process with the potential to long-term produce a product that meets customer requirements. All customers required steps within the PPAP have been documented and the specific requirements of the customer have been met [28].

\section{CONCLUSION}

The research paper presents the methodology of innovation of the organizational measuring business processes based on the implementation of the internationally recognized standard ISO/TS 16949 - Quality Management System - Particular requirements for the application of ISO 9001:2015 in organizations for automotive production and relevant spare parts and measuring system as a key element of products management quality. The aim was to carry out the qualification of toothed shafts into series production using the PPAP. Formal confirmation of the success of production expertise is the development and transmission of a relevant PPAP documentation with the subsequent formal approval of series production to customer representatives.
Defining a quality program and planning are tied to the needs and expectations of the customer. When focusing on any product program, meeting customer needs while ensuring competitive value is the primary goal. It is essential that the needs and expectations of the customer are ensured and understood in the process of modern product quality planning. Depending on the product development process, customer expectations and needs, process inputs and outputs may change. A detailed review and understanding of the control specifications provides the organization's product quality planning team with assistance in identifying the life, functionality, and appearance requirements of the component or configuration in question. The selection range, frequency, and acceptance criteria of these parameters are defined in the technical specifications' selection for inter-operational tests. If not defined, the scope and frequency of the selection must be determined by the organization and must be stated in the control and management plan.

The knowledge gained through a detailed familiarization with the PPAP including the use of quality tools allow to recommend further activities to improve the production and inspection processes applicable to series production of the automotive industry. The purpose of the PPAP is to determine whether the organization has properly understood all customer requirements that are listed in the specifications and technical product design records. PPAP further verifies whether the process has the potential to produce the product in the series production so that the customer's requirements will be met, at real production volume and the agreed production speed.

\section{ACKNOWLEDGEMENT}

This paper was supported by the Scientific Grant Agency od the Ministry of Education of Slovak republic under grant VEGA 1/0651/2018 - Research of institutional environment influence to the corporate social responsibility, consumer's satisfaction and performance of the company.

\section{REFERENCES}

[1] J. Smutná, R. Farana. "Understanding the quality concept in the higher education". Acta Montanistica Slovaca, vol. 15, no 1,2010 , pp. 54-57.

[2] K. Chad. "Effective ISO/TS 16949 Audits". Quality, vol. 45, no 2, 2006, pp. 44-47.

[3] P.W. Brennecke. "Safety Aspects in Radioactive Waste Management". Acta Montanistica Slovaca, vol. 12, no 1, 2007, pp. 42-47.

[4] A. Lavrin, M. Zelko. "Moving toward the digital factory in raw material resources area". Acta Montanistica Slovaca, vol. 15, no 3, 2010, pp. 225-231.

[5] A.B. Pop, A.M. Tîţu. "Implementation of Advanced Product Quality Planning in the Aerospace Industry A Way to improve the Quality Management. Calitatea: Access la Success; Bucharest". Quality - Access to Success, vol. 21, no 177, 2020, pp. 56-61.

[6] J. Kuba. (2012). Production and Part Approval Process. Available: <https://members.marticonet.sk/jkuba/QMS/ PPAP\%20prirucka.pdf>. 
[7] S. Hasan, S. Shah and J. Gao. "A collaboration framework to support decision making in new product development with the supply chain," In Proceedings of the $11^{\text {th }}$ International Conference on Manufacturing Research (ICMR2013), Cranfield University, UK, $19^{\text {th }}-20^{\text {th }}$ September 2013, pp. 531-536.

[8] D.C. Montgomery. Introduction to Statistical Quality Control. Sixth Edition. New York: John Wiley \& Sons, Inc. 2009.

[9] Z. Alot. "The Model of the Production Process for the Quality Management". Foundations of Management, vol. 9, no 1, 2017, pp. 43-60.

[10] Z. Alot, W. Izdebski." Identification of model of the production process for the purposes of quality management." Materialy dokladov Mezhdunarodnoy nauchno-prakticheskoy konferentsii "Sotsial'no-ekonomi-cheskoye razvitiye organizatsiy iregionov Belarusi: effektivnost' iinnovatsii" (ed. Vankevich Ye.V., Sharstnev V.L., Kasayeva T.V., Prokof'yeva N.L., Savitskaya T.B., Yasheva. Witebsk: UO "WGTU", 2015, pp. 84-96.

[11] J. Gonos, M. Muchová, L. Domaracká. “Controlling as an efficient tool for the strategic management of industrial companies". Acta Montanistica Slovaca, vol. 21, no 3, 2016, pp. 229-237.

[12] K. Jiang, D.P. Lepak, J. Hu and J.C. Baer. "How Does Human Resource Management Influence Organizational Outcomes? A Meta-analytic Investigation of Mediating Mechanisms". AMJ, vol 55, 2012, pp. 1264-1294, https://doi.org/10.5465/amj.2011.0088.

[13] D.F. Dianda, M.B. Quaglino, J.A. Pagura. "Performance of Multivariate Process Capability Indices Under Normal and Non-Normal Distributions". Quality and Reliability Engineering International, vol. 32, no 7, 2016, pp. 2165-2632.

[14] H.Ch. Co. Effectiveness of high-priority supplier selection process for advanced product quality planning implementation on new model programs at a North American automaker. Eastern Michigan University, ProQuest Dissertations Publishing, 2000.

[15] A.R. Mileham, S.J. Culley, G.W. Owen, R.I. McIntosh. "Rapid changeover - a pre-requisite for responsive manufacture". International Journal of Operations \& Production Management, vol. 19, no 8, 1999, pp. 785-796.

[16] B. Tanguy, J. Besson, R. Piques, A. Pineau. "Ductile to brittle transition of an A508 steel characterized by Charpy impact test: Part II: Modelling of the Charpy transition curve". Engineering Fracture Mechanics, vol. 72, no 3, 2005, pp. 413-434.

\author{
Andrea Seňová \\ ORCID ID: 0000-0001-5006-7535 \\ Technical University of Kosice \\ Faculty of Mining, Ecology \\ Process Control and Geotechnology \\ Letna 9, 04200 Kosice, Slovak Republic \\ e-mail: andrea.senova@tuke.sk

\section{Lenka Štofová} \\ ORCID ID: 0000-0002-1200-0441 \\ University of Economics in Bratislava \\ Faculty of Business Economics with seat in Kosice \\ Tajovského 13, Košice, Slovak Republic \\ e-mail: lenka.stofova@euba.sk
}

[17] J.S. Oakland. Total Quality Management and Operational Excellence: Text with Cases. Fourth Edition. New York, Abingdon, Oxon: Routledge. 2014.

[18] K.L. Chen, K.S. Chen, R.K. Li. "Suppliers capability and price analysis chart". International Journal of Production Economics, vol. 98, no 3, 2005, pp. 315-327.

[19] M.A. Broy. "A logical approach to systems engineering artifacts: semantic relationships and dependencies beyond traceability - from requirements to functional and architectural views". Software and Systems Modeling, vol. 17, no 2. 2018, pp. 365-393.

[20] F. Misopoulos, R. Michaelides, M. Salehuddin, V. Manthou, Z. Michaelides. "Addressing Organisational Pressures as Drivers towards Sustainability in Manufacturing Projects and Project Management Methodologies". Sustainability, vol. 10, no 6, 2018.

[21] Kulkarni, Damodar, Deore, Pankaj. "Cost reduction in Lowcost Emerging Economies for Sustainable Growth - Principles, Processes, Tools \& Techniques". SAE Technical Paper Series. 2015.

[22] Hebei Shida Seal Group Co. (2016). Ltd. Production Part Approval Process (PPAP). Available: <http://www.shidarubber.com/technical-resources/production-part-approval-process-ppap/>.

[23] Y. J. Chen. "Structured methodology for supplier selection and evaluation in a supply chain". Journal of Information science, vol. 18, no 1, 2010, pp. 1651-1670.

[24] PPAP Documents. (2017). Available <http://ppapdocuments.com/ppap-documents/.

[25] I. Petrašová I. Proces schvalování dílů do sériové výroby (PPAP): referenční príručka. 4. vyd. Praha: Česká společnost pro jakost. 69 p. 2006.

[26] B. Jung Hyun, H. Tack-Don. „PPAP: Perspective Projection Augment Platform with Pan - Tilt Actuation for Improved Spatial Perception“. Sensors, vol. 19, no 12, 2019.

[27] D. Edgar. "Valid data demanded". Modern machine shop, vol. 88, no 11, 2016.

[28] D. McCoy. Production Part Approval Process (PPAP). Global Standard. 2010.

\section{Petra Szaryszová}

ORCID ID: 0000-0002-1128-2280

University of Economics in Bratislava

Faculty of Business Economics with seat in Kosice

Tajovského 13, Košice, Slovak Republic

e-mail: petra.szaryszova@euba.sk

\section{Jaroslav Dugas \\ ORCID ID: 0000-0002-0480-639X}

University of Economics in Bratislava

Faculty of Business Economics with seat in Kosice

Tajovského 13, Košice, Slovak Republic

e-mail: jaroslav.dugas@euba.sk 